\title{
FEDERAL CIVIL PROCEDURE: DETERMINATION OF AMOUNT IN CONTROVERSY
}

$\mathrm{O}_{\mathrm{NE}}$ prerequisite to diversity jurisdiction in the federal courts is that the amount in controversy exceed in value the sum of $\$ 10,000 .^{1}$ The recent Supreme Court case of Horton v. Liberty Mutual Insurance Company ${ }^{2}$ presented the question of how to determine the amount in controversy.

In the Horton case, a worker had filed a claim with the Texas Industrial Accident Board for disability benefits of $\$ 14,035$, but had been awarded only $\$ \mathrm{I}, 050$. The insurer instituted a diversity action in a United States district court to set aside the award. ${ }^{3}$ The worker, also dissatisfied with the award, instituted an action in a state court for $\$ 14,035$, then moved to dismiss the insurer's federal court action for lack of jurisdiction, simultaneously filing a counterclaim for $\$ 14,035$ contingent upon denial of the motion to dismiss. The district court dismissed the insurer's suit on the ground that the jurisdictional amount was not present. ${ }^{4}$ The Court of Appeals, relying on Texas law, found the requisite amount to be involved. ${ }^{5}$ After granting certiorari, the

1 "The district courts shall have original jurisdiction of all civil actions where the matter in controversy exceeds the sum or value of $\$ 10,000$, exclusive of interest and costs. ..." 28 U.S.C. $\$ \times 332$ (1958). It also is an element of federal question jurisdiction. 28 U.S.C. $\$ 1331$ (1958).

But of. 28 U.S.C. $\$ \S \times 333-60$ (1958), where Congress has provided that the amount in controversy shall be immaterial in certain types of cases, principally those dealing with admiralty, bankruptcy, internal revenue, patents, trademarks, and copyrights.

${ }_{367}$ U.S. 348 (1961).

3 Texas law permits any dissatisfied party in a workmen's compensation action to "bring suit in the county where the injury occurred to set aside said final ruling and decision," and the issues shall be heard "upon trial de novo, and the burden or [sic] proof shall be upon the party claiming compensation." In such de novo trial, the recovery may not exceed "the maximum compensation allowed under the provisions of this law." TeX. Rev. Crv. Stat. art. $8307, \S 5$ (1956).

In its memorandum opinion, the district court approved the discussion of the problem in National Sur. Corp. v. Chamberlain, I7 F. Supp. 59x. (N.D. Tex. 1959 ). Brief for Petitioner, Horton v. Liberty Mut. Ins. Co., 367 U.S. 348 (xg6I), p. 4. In the Chamberlain case the court said: "[T] he amount in controversy in this suit is the value of the right of plaintiff National Surety Corporation to be free from the $\$ 2$,ooo liability fastened upon it by the award of the Industrial Accident Board." I7 I F. Supp. at 597-98. Accord, Travelers Ins. Co. v. Cook, 172 F. Supp. 7 10 (N.D. Tex. 1959).

${ }^{E}$ Liberty Mut. Ins. Co. v. Horton, 275 F.2d 148 (5th Cir. 1960), 39 Texas L. 
Supreme Court affirmed the decision of the Court of Appeals by a five to four vote. Mr. Justice Black, speaking for the Court, found from the allegation in the complaint that the worker had a counterclaim in excess of $\$ 10,000$ and from the record as a whole that the jurisdictional amount was "unquestionably" involved."

Heretofore, the lower federal courts have evolved three formulae for detemining the amount in controversy. ${ }^{7}$ Of the two formulae applied in coercive actions, the first has been referred to as the "plaintiff viewpoint" rule, under which the amount in controversy is determined by the value to the plaintiff of the right which he asserts in good faith in his pleading. ${ }^{8}$ This rule, followed in many lower federal courts,"

REv. 343 (196I). The Court of Appeals placed its decision on alternate grounds. For the first gronnd, the court relied on the case of Booth v. Texas Employers' Ins. Ass'n, 132 Tex. 237, 123 S.W.2d 322 (1938), in which the Texas Supreme Court held that where the award of the Board was less than the amount of the claim of the worker, the claim determined the amount in controversy in the state courts. Applying this holding, the court concluded that the worker's claim for $\$ 14,035$ governed and jurisdiction was shown. 275 F.2d at 150 .

As a "further and additional" ground, the court cited cases holding that if a compulsory counterclaim is filed which is in excess of $\$ 10,000$, jurisdiction is established, regardless of the complaint. 275 F.2d at 152 .

Professor Moore has criticized the decision of the Court of Appeals: ". . . [T] proper ruling was that of the district court in Chamberlain." I MOORE, FEDERAx. PRACTICE [ 0.93, at 859 (2d ed. 1960). [Hereinafter cited as MoORE.] See note 4 supra.

367 U.S. at $353-54$.

As to the first ground of decision in the Court of Appeals, the Supreme Court rejected the applicability of Texas law to determine the jurisdictional amount, noting that such a determination was "a federal question to be decided under federal standards." Id, at 352. However, the Court said that "the federal courts must, of course, look to state law to determine the nature and extent of the right to be enforced in a diversity case." Id. at 352-53.

.. The second ground of decision was ignored. (See note 5 supra.)

'See generally Dobie, Jurisdictional Amount in United States District Courts, 38 HaRv. L. REv. 733 (1925); Ilsen \& Sardell, The Monetary Minimum in Federal Court Jurisdiction, 29 ST. JohN's L. REv. 1, 183 (1955); Comment, 46 CalIF. L. REv. 601 (1958); Note, 73 HARv. L. REv. 1369 (1960).

'Dobie, supra note 7, at 734 . In this article, which first explicitly stated this rule, Dobie discusses earlier Supreme Court cases which speak to the problem. Id. at 742-44. For an example of the application of this rule, see Cowell v. City Water Supply Co., 121 Fed. 53 (8th Cir. 1903). Here the plaintiff sued to cancel mortgages on the waterworks totaling $\$ 475,000$. The court, however, held that the value to the plaintiff was only that of his proportional share or $1 / 325$. The case was dismissed for lack of the requisite jurisdictional amount.

A coercive action is one in which the judgment can be enforced directly by an order of execution of proceedings in conternpt of court.

'See, e.g., Stewart v. Shanahan, 277 F.2d 233 (8th Cir. 196o); Wade v. Rogala, 
meshes well with the doctrine that jurisdiction is to be determined from the initial pleading. ${ }^{10}$ It lends itself to relatively easy application and provides a measure of certainty in determining whether jurisdiction attaches. $^{11}$

In coercive actions authority has also arisen for the "alternate valuation" rule, under which the amount in controversy is measured by the pecuniary result to either party which a judgment in the case would directly produce. ${ }^{12}$ This standard' recognizes that a federal forum

270 F.2d 280 (3d Cir. 1959); Payne v. State Farm Mut. Auto. Ins. Co., 266 F.2d 63 (5th Cir. 1959); Fireman's Fund Ins. Co. v. Railway Express Agency, 253 F.2d 780 (6th Cir. 1958); Wyoming Ry. v. Herrington, r6 $_{3}$ F.2d roo4 (roth Cir. r947); Purcell v. Summers, 126 F.2d 390 (4th Cir.), cert. denied, 317 U.S. 640 (1942); Central Mexico Light \& Power Co. v. Munch, 116 F.2d 85 (2d Cir. r940); Gavica v. Donaugh, 93 F.2d 173 (9th Cir. 1937 ).

In St. Paul Mercury Indem. Co. v. Red Cab Co., 303 U.S. 283,288 (1938), the Supreme Court said: "the rule governing dismissal for want of jurisdiction . . . is that . . the sum claimed by the plaintiff controls if the claim is apparently made in good faith." It has been claimed that this decision was an adoption of the plaintiff viewpoint rule by the Supreme Court. See I MOORE I 0.91, at 827 (2d ed. I960). But see Thomson v. Gaskill, 315 U.S. 442,447 (1942), where the Court held the amount to be determined by the judgment's "pecuniary consequence to those involved in the litigation."

Courts often confuse the "good faith" test of the St. Paul case, supra, with: the plaintiff viewpoint rule and cite the cases interchangeably.

${ }^{10}$ For a statement of the doctrine that the jurisdiction is determined from the initial pleading, see St. Paul Mercury Indem. Co. v. Red Cab Co., 303 U.S. 283 (r938); Pinel v. Pinel, 240 U.S. 594 (1916); Commercial Cas. Ins. Co. v. Fowles, 154 F.2d 884 (9th Cir. 1946); Sparks v. England, 113 F.2d 579 (8th Cir. 1940); Zicos v. Dickmann, 98 F.2d 347 (8th Cir. r938).

The concurrence of these two doctrines allows a federal court to determine jurisdiction merely by looking to the complaint. See also FED. R. Crv. P. 3 .

${ }^{11}$ See I MOORE I 0.91 , at 828 (2d ed. 1960).

${ }^{12}$ See, Ridder Bros. v. Blethen, 142 F.2d 395 (9th Cir. 1944); Ronzio v. Denver \& R.G.W.R.R., II6 F.2d 604 (roth Cir. I940); King v. Southern Ry., I 9 Fed. ror6 (C.C.N.D. Ga. 1902); Doggett v. Hunt, 93 F. Supp. 426 (S.D. Ala. 1950); Sterl v. Sears, 88 F. Supp. 431 (N.D. Tex. 1950); Shipe v. Floral Hills, Inc., 86 F. Supp. 985 (W.D. Mo. 1949); Griffith v. Enochs, 43 F. Supp. 352 (W.D. La. 1942); New Jersey Fed'n of Young Men's and Young Women's Hebrew Ass'ns v. Hoffman, 25 F. Supp. 687 (M.D. Pa. 1938) ; Ross v. Southern Ry., 20 F. Supp. 556 (W.D.S.C. 1937); Armstrong v. Townsend, 8 F. Supp. 953 (S.D. Ind. 1934).

The leading case, Elliott v. Empire Natural Gas Co., 4 F.2d 493 (8th Cir. I925), relies heavily on language in Smith v. Adams, 130 U.S. 167, 175 (1889), where the Court said, "it is conceded that the pecuniary value of the matter in dispute may be determined ... by the pecuniary result to one of the parties ... from the judgment."

For an illustration of the application of this rule, see Ronzio v. Denver \& R.G.W.R.R., supra. In this case, the plaintiff brought an action to qniet title in the water rights of a certain stream. It was stipulated by the parties that the value of the water for the plaintiff's agricultural purposes was $\$ 2,000$, while for use by the de- 
should not be denied if the value of either party's interest exceeds the requisite amount. ${ }^{13}$

In actions for declaratory judgments courts have determined the amount in controversy in a more realistic manner. ${ }^{14}$ They have considered the broadest possible dimensions of the controversy, rather than relying entirely on that which is pleaded in the complaint. ${ }^{15}$ Thus,

fendant railroad, the water was valued in excess of $\$ 3,000$ (then the jurisdictional amount). The court found jurisdiction by looking to the value of the defendant's interest. Obviously the result would have been different under the "plaintiff viewpoint" rule. See note 8 supra.

${ }^{13}$ See Sterl v. Sears, supra note 12, at 432 . The term "alternate valuation rule" was suggested by Comment, 46 CALIF. L. REv. 601 (1958). For a discussion of situations where the defendant's interest presents a "more rational basis" for determining the amount in controversy, see Note, 73 HARV. L. REV. 1369 (1960).

These rules are not inflexible rules of law, however, for courts often have molded them to accomplish desired results. For example, in Food Fair Stores, Inc. v. Food Fair, Inc., 177 F.2d 177 ( 1 st Cir. 1949), the plaintiff sued for an injunction to prohibit the defendant from using the name "Food Fair." The court, purporting to follow the "plaintiff viewpoint" rule, held that jurisdiction would attach if the plaintiff's net assets, sales or advertising expenses exceeded $\$ 10,000$. Since the logical measure of jurisdictional amount is the loss of revenue sustained from the infraction, the decision would seem to be based on an unarticulated policy of allowing these suits in federal court, possibly because of the similarity to situations covered by federal regulation. For other cases adhering to the rule set down in the Food Fair case, see Beneficial Industrial Loan Corp. v. Kline, 132 F.2d 520 (8th Cir. 1942); Nash-Kelvinator Corp. v. California Refrigerator Repair Shop, II F.R.D. 313 (S.D. Cal. 1950); Baker v. Master Printers Union, 34 F. Supp. 808 (D.N.J. 1940). Contra, e.g., SegramDistillers Corp. v. New Cut Rate Liquors, Inc., 245 F.2d 453 (7th Cir. 1947); Sunbeam Corp. v. Richardson, 144 F. Supp. 583 (W.D. Ky. 1956).

For an example of cases in which the court has molded the rule to deny jurisdiction, see Pianta v. H. M. Reich Co., 77 F.2d 888 (2d Cir. 1935), where, in a suit to have a receiver appointed for the company, the court held that the plaintiff's claim, not the assets of the company, governed the jurisdictional amount. Such a decision results in the favoring of proceedings under the Bankruptcy Act rather than a receivership under state law.

14 Such an approach is due in part to the fact that the Declaratory Judgment Act, 28 U.S.C. $\S \S 2201-02$ (1958), is a procedural act and as such is to be interpreted broadly. Skelly Oil Co. v. Phillips Petroleum Co., 339 U.S. 667 (1950); Aetna Life Ins, Co. v. Haworth, 300 U.S. 227 (1937); Simmonds Aerocessories, Ltd. v. Elastic Stop Nut Corp., 257 F.2d 485 (3d Cir. 1958); Donnely v. Mavar Shrimp \& Oyster Co., 190 F.2d 409 ( 5 th Cir. 1951). This approach also aids in implementing the policy of allowing early suits to prevent the accrual of needless damage. Davis v. American Foundry Equip. Co., 94 F.2d 44r (7th Cir. 1938); E. Edelmann \& Co. v. Triple-A Specialty Co., 88 F.2d 852 (7th Cir.), cert. denied, 300 U.S. 680 (1937).

${ }^{26}$ ' $\mathrm{It}$ is the nature of the controversy, not the method of its presentation or the particular party who presents it, that is determinative [of the amount in controversy]." Aetna Life Ins. Co, v. Haworth, 300 U.S. 227, 244 (1937).

See, e.g., American Cas. Co. v. Howard, 173 F.2d 924 (4th Cir. 1949); Mutual 
where the validity of an entire commercial or insurance contract is called into question, the face value of the contract, not the amount recoverable in a coercive action, determines the amount in controversy. ${ }^{16}$

On the facts of the Horton case, it is debatable whether the Court applied the "alternate valuation" or the "plaintiff viewpoint" rule. Under Texas workmen's compensation law, if either party initiates court action, the award of the Board becomes void, and the trial is de novo. ${ }^{17}$ In such a de novo trial the defendant would have the opportunity to prove liability up to $\$ 14,035$ on the part of the insurer. ${ }^{18}$ Thus under the "plaintiff viewpoint" rule, the insurer would have a right to be free not only of a $\$ I, 050$ award, but of a potential claim of $\$ I 4,035 .^{18}$ Arguably, however, the Court construed the insurer's right as merely a right to set aside the Board's award. Under this analysis it would seem

Life Ins. Co. v. Moyle, I I 6 F.2d 434 (4th Cir. I 940); E. Edelmann \& Co. v. Triple-A Specialty Co., supra note 14.

${ }^{10}$ Non-insurance contracts: see Davis v. American Foundry Equip. Co., 94 F.2d 441 (7th Cir. 1938); M. Swift \& Sons, Inc. v. Lemon, 24 F.R.D. 43 (S.D.N.Y. 1959). Insurance contracts: see Hartford Acc. \& Indem. Co. v. Northwest Nat. Bank, 228 F.2d 391 (7th Cir. 1955); Hardware Mut. Cas. Co. v. Schantz, 178 F.2d 779 (5th Cir. 1949); Home Ins. Co. of N.Y. v. Trotter, r30 F.2d 800 (8th Cir. 1942).

However, where the only question is the validity of a certain claim under a policy, the amount of the claim, not the face value of the policy, is usually held to measure the amount in controversy. Kaufman v. Liberty Mut. Ins. Co., 245 F.2d 9x8 (3d Cir. 1957); American Cas. Co. v. Howard, supra n.x 5 ; Mutual Life Ins. Co. v. Moyle, supra n.15. Contra, C. E. Carnes \& Co. v. Employer's Liability Assur. Corp., Io I F.2d $739^{\circ}$ (5th Cir. 1939).

In cases arising under federal question jurisdiction, notably cases involving patent infringement, the courts have consistently held that "a declaratory judgment action to adjudicate the validity and infringement of a patent is within the jurisdiction of the federal courts .... whether the action is brought by the patentee or the alleged infringer." Eastman Kodak Co. v. Velveray Corp., 175 F. Supp. 646, 648 (S.D.N.Y. 1959). Accord, E. I. Du Pont de Nemours \& Co. v. Byrnes, ror F.2d 14 (2d Cir. I939); E. Edelmann \& Co. v. Triple-A Specialty Co., 88 F.2d 852 (7th Cir.), cert. denied, 300 U.S. 680 (1937); Formaster Corp. v. G. A. Bishop Co., 138 F. Supp. I15 (S.D.N.Y. I956). This is true even though the alleged infringer, to state a federal question, must anticipate the basis of the defendant's claim in the patent laws, contrary to the doctrine of Louisville \& N.R.R. v. Mottley, 2 II U.S. I49 (1908), that a federal question cannot be anticipated.

${ }^{17}$ TEX. REv. Civ. STAT. art. $8307, \S_{5}$ (1956), supra note 3 , as interpreted by the Texas Supreme Court in Booth v. Texas Employers' Ins. Ass'n, 132 Tex. 237, 123 S.W.2d 322 (1938).

${ }^{18}$ See TEX. REv. Civ. STaT. art. $8307, \S_{5}$ (1956), supra note 3 .

${ }^{10}$ The Court pointed out that the insurer's complaint alleged that the worker "has claimed, now claims and will claim" $\$ 14,035$; and, since this had been neither disclaimed nor denied, the worker failed to show to a "legal certainty" that a $\$ 14,035$ claim was not involved. 367 U.S. at 353 . 
that the "alternate valuation" rule was applied, for a declaration of the insurer's non-liability would deny to the worker a possible $\$ 14,035$ judgment. ${ }^{20}$

The language of the opinion is much broader than either rule for coercive actions requires. Moreover, the dissenting Justices, in an opinion by Mr. Justice Clark, strongly urge that the majority in essence has eliminated the distinction between declaratory judgments and conventional actions by applying the broad amount-in-controversy standard used in declaratory judgment actions to a suit for coercive relief. Thus, according to the dissent, cases which normally would be styled declara. tory judgment cases could be brought as coercive actions, eliminating the discretion of the federal courts under the Declaratory Judgment Act and forcing them to take cases inappropriate to federal adjudication. ${ }^{21}$ The dissent further argues that the majority allows the plaintiff to affix jurisdiction by alleging a possible counterclaim, a holding which would greatly expand the jurisdiction of the federal courts. ${ }^{22}$

Another problem raised both by the majority and the dissenting opinions involves the 1958 amendment to the judicial code that prohibits the removal of workmen's compensation cases to the federal courts. ${ }^{23}$ The legislative history of the amendment indicates that the purpose was to eliminate the large number of removal cases $^{24}$ in those

${ }^{20}$ The Court pointed out that "the claim before the Board was $\$ 14,035$; the state court suit of the petitioner asked that much; the conditional counterclaim in the federal court claims the same amount. Texas law under which this claim was created and has its being leaves the entire $\$ 14,035$ claim open for adjudication in a de novo court trial regardless of the award." 367 U.S. at $353-54$.

${ }^{21}{ }^{6} 7$ U.S. at 359 .

It is settled that the Declaratory Judgments Act, 28 U.S.C. $\$ \$ 2201-02$ (1958), is essentially equitable in nature and under it, the courts may decline to exercise their equitable jurisdiction if sufficient reason exists. Public Service Comm. of Utah v. Wycoff Co., 344 U.S. 237 (1952); Brillhart v. Excess Ins. Co. of America, 316 U.S. 491 (1942). Had the Horton case been styled a declaratory judgment, it is probable that the court would have dismissed it under the exercise of this discretion, for the case concerned a state-crented right and state statutes. See 6 MOORE I 57.08, at 3035, and cases cited therein.

${ }^{22} 367$ U.S. at 358 .

${ }_{28}^{28}$ U.S.C. $\$ 1445$ (c) (1958). This amendment also raised the jurisdictional amount to $\$ 10,000 ;$ provided that a corporation is deemed a citizen of the state of its principal place of business as well as of the state of incorporation; and gave district court judges a discretionary power to impose costs on a plaintiff recovering less than $\$ 10,000$. 28 U.S.C. $\$ \$ 1331-32$ (1958). Each part of the amendment was aimed at reducing the caseload in the federal courts. 367 U.S. at $350-51$.

${ }^{24}$ In Texas in 1957, there were 2147 workmen's compensation cases instituted in federal courts, of which 1148 came by removal from the state courts. S. REP. No. 
states where a workmen's compensation claim is heard de novo in the state court. ${ }^{25}$ The Horton case seems to circumvent the spirit of the amendment by allowing the insurer to gain a federal forum simply by filing to set aside whatever award is made by the Board and alleging a counterclaim by the worker in excess of the jurisdictional amount. ${ }^{26}$

The view of the majority is in line with the modern judicial emphasis on substance rather than form. ${ }^{27}$ The majority opinion, however, lends itself to the interpretation and criticisms of the dissent, ${ }^{28}$ for the

1830 at 8. (Jurisdictional amount was then $\$ 3,000$.) The 1958 amendment was intended to eliminate all removal cases, and, by the increase in jurisdictional amount, many of the original suits. The Horton case will go far to vitiate the effectiveness of the prohibition on removal by allowing these actions to be brought as original ones.

${ }^{25}$ The report of the Senate Judiciary Committee specifically mentioned Alabama, Louisiana, New Mexico and Texas. S. REP. No. 1830, 85th Cong., 2d Sess. 34 (1958) [hereinafter cited as S. REP. No. 1830]. Statutes in Alabama, Louisiana and New Mexico create a right in the worker to be instituted in court. ALA. CoDE tit. 26, § 297 (1958); LA. Rev. STAT. § $23: 1311$ (1950); N.M. STAT. ANN. § 59-10-13.7 $(1960)$. Texas has an administrative hearing, but provides that a trial de novo may be had by any dissatisfied party. TEx. Rev. Civ. Stat. art. 8307, $\$ 5$ (1956).

Removal inay be had only from a trial de novo, for the U.S. district courts have no jurisdiction over appeals taken from state administrative hearings. Chicago, R.I. \& P.R.R. V. Stude, 346 U.S. 574 (1953).

${ }^{20}$ The majority opinion noted explicitly that Congress had barred removal of such cases, but at the same time had left unchanged "the old language which ... permits civil suits to be filed in federal courts in cases where there are both diversity of citizenship and the prescribed jurisdictional amount." 367 U.S. at 352 . A virtual appeal for legislative action to close the loophole was made: "Congress could very easily have used language to bar filing of workmen's conpensation suits by the insurer as well as removal of such suits, and it could easily do so still." Ibid.

${ }^{27}$ In the case of Beacon Theatres, Inc. v. Westover, 359 U.S. 500 (1959), the Court was faced with a somewhat analogous situation. The plaintiff sought a declaratory judgment of his rights under a contract with the defendant and asked for an injunction against possible suits. The defendant counterclaimed for treble damages under the anti-trust laws, and asked for a jury trial on the factual issues. The lower court felt that the complaint was essentially equitable in nature and no jury trial was possible. The Supreme Court granted jury trial, feeling that although the availability of declaratory relief allowed the natural defendant to bring the suit, the relief should not go so far as to deprive the natural plaintiff of his right to jury trial.

${ }^{28}$ The dissenter's fear of wholesale allegations of possible counterclaims should be assessed in light of the fact that the allegation in this case was well supported by extrinsic facts. The fear of the dissent, however, is made more credible by a recent unreported case, Hart $v$. United States Fid. and Guar. Co., decided by the District Court for the Northern District of Texas on June 16, 1961, cert. denied, 30 U.S.L. WEEx 3145 (U.S. Nov. 7, 196I). In the case, a worker filed a general claim before the Industrial Accident Board, claiming no specific amount. He was awarded \$gro. The insurer immediately filed suit in federal district court to set aside the award, alleging that the worker's claim was inore than $\$ 10,000$. The worker counterclaimed for $\$ 6,3$ Io. He unsuccessfully challenged the jurisdiction of the court. It would seem 
Court does seem to have adopted the broad standard used in declaratory judgments to determine the amount in controversy. ${ }^{29}$ The court's opinion fails to give a definite guideline for the lower courts, so that the uncertainty attendant to the application of the earlier rules has been replaced by uncertainty as to the proper interpretation of the holding in the instant case. Moreover, the immediate effect of the Horton case is to vitiate somewhat the effectiveness of the 1958 amendment which sought to reduce workmen's compensation litigation in the federal courts. Congressional action will be needed to effect the aims of the amendment, but it is also to be hoped that the Supreme Court will clarify its standard for determination of the amount in controversy.

that the district court, relying greatly on the Horton case, maintained jurisdiction on the ground that the counterclaim could have been more than $\$ 10,000$. Brief of Petitioner, P. 3, Hart v. United States Fid. and Guar. Co. (N.D. Tex. 1961).

${ }^{20}$ "Thus the record before us shows beyond a doubt that the award is challenged by both parties and is binding on neither; that petitioner claims more than $\$ 10$,000 from the respondent and the respondent denies it should have to pay petitioner anything at all. No matter which party brings it into court, the controversy remains the same; it involves the same amount of money and is to be adjudicated and determined under the same rules." ${ }_{367}$ U.S. at 354 . The language is quite similar to that of the Court in Aetna Life Ins. Co. v. Haworth, 300 U.S. 227 (1937), a declaratory judgment case. The pertinent language in the Haworth case is quoted in note $\times 5$ supra. 